\title{
The link between food, psychosocial factors and suffering
}

\author{
Legătura între alimente, factorii psihosociali şi suferinţă
}

\author{
Irina Mihaela Matran', Dan L. Dumitraşcu² \\ ${ }^{1}$ Universitatea de Medicină şi Farmacie „Iuliu Haţieganu“, Cluj-Napoca, România \\ 2Departamentul Medical 2, Universitatea de Medicină şi Farmacie „Iuliu Haţieganu“,Cluj-Napoca, \\ România
}

\begin{abstract}
The quality of life of each individual is reflected in his/her well-being state, capacity of copig, satisfaction and happiness. Health is a complex notion involving physical, psychological and social wellbeing and a balance beween the aspirations and the achievements of each person. To this, one should ad biological factors: morphological, functional homeostasy as well as the psychological factors: emotions, cognitions and behavioral factors. By specific physyiological processes, food and its ingestion is also very important in maintaining the health and a high quality of life. The quality of the animal food eaten depends on its production procedures including feeding and treating the animals. The value of vegetal food depends on the geographic provenance and also on production style: intensive or biological.

The consumption of the food and its perception depend on the palatability of the meals. The eating environement is also important: eating alone or with the family, in the presence of music or noise, in hurry or not etc. Mass-media has an important role in the development of eating behaviors. Listening to music or even by music sung or played by a certain performer, or association of drinks may improve hedonistic expectancies. This is a review on the connection between food, psychosocial factors and disease.
\end{abstract}

Keywords: disease, food, psychosocial factors

\section{REZUMAT}

Calitatea vieții fiecărui individ se regăseşte în starea de bine, sănătate, adaptare, satisfacţie, bucurii şi fericire. Prin complexitatea sa, sănătatea cuprinde bunăstarea fizică, psihică şi socială, echilibrul între psihicul şi fizicul fiinţei umane şi îndeplinirea adecvată a aspiraţiilor şi nevoilor sale. La acestea se adaugă aspectul biologic, prin integritatea morfologică, funcţională şi homeostazia internă, psihologic, din punct de vedere cognitiv, emoţional şi comportamental, respectiv social şi spiritual. Prin procesele fiziologice specifice, alimentele și modul de consumare a acestora sunt esențiale pentru sănătate și calitatea vieții. Calitatea biologică a produselor alimentare de origine animală consumate este condiţionată de specia şi rasa, vârsta, modul de creştere, inclusiv hrana (furajele) şi tratamentele aplicate animalelor. Valoarea biologică a alimentelor de origine vegetală este direct proporţională cu zona geografică şi zona de relief în care sunt cultivate furajele folosite în hrana animalelor şi de tipul agriculturii aplicate - intensivă sau ecologică.

Modul de consum şi de percepţie a alimentelor influenţează percepţia mâncării şi este influenţat de textura, gustul, aroma şi culorile alimentelor. La acestea se adaugă ambientul, muzica, zgomotul şi stresul, precum şi dacă sunt consumate în familie, cu prietenii sau singuri. Mass-media este un factor determinant în modul de consum şi de percepţie a alimentelor, atât în România, cât şi în alte ţări. Hedonismul este influenţat inclusiv de muzica ascultată în timpul consumului de alimente sau de băuturi, de tipul alimentelor şi băuturilor, precum şi de celebrităţile muzicale care promovează un aliment sau o băutură.

Prezenta lucrare arată legătura între alimente, factorii psihosomatici şi suferinţă.

Cuvinte cheie: aliment, boala, factori psihosociali

Calitatea vieții a fiecărui individ se regăseşte în starea de bine, sănătate, adaptare, satisfacție, bucurii şi fericire. Prin complexitatea sa, sănătatea cuprinde bunăstarea fizică, psihică şi socială, echili- bru între psihicul şi fizicul ființei umane şi îndeplinirea adecvată a aspiraţiilor şi nevoilor sale (1). La acestea se adaugă aspectul biologic, prin integritatea morfologică, funcțională şi homeostazia 
internă, psihologic, din punct de vedere cognitiv, emoțional şi comportamental, respectiv social şi spiritual (1). Prin procesele fiziologice specifice, alimentele şi modul de servire a acestora sunt esențiale pentru sănătate şi calitatea vieții, indiferent de vârstă, acestea contribuind şi la dezoltarea culturală, socială şi psihologică $(2,3)$ şi obținerea satisfacției (3-5). Având în vedere posibilele complicații ale anumitor patologii, ca de exemplu diabet $(6$, $7,14,18,24)$, tumoare orală (8) sau implanturi dentare (10), leziunea măduvei spinării (9), cancer $(11,15,17,20-22,26,27)$, boli cardiovasculare $(12$, 23), scleroză multiplă (13), infecția cu Pseudomonas aeruginosa (16) şi colită ulceroasă $(19,25)$, reflux gastroesofagian (28-33), calitatea vieții este profund afectată. Indiferent de starea de sănătate şi/ sau patologie, calitatea biologică a produselor alimentare de origine animală consumate este condiționată de specia şi rasa, vârsta, modul de creştere, inclusiv hrana (furajele) şi tratamentele aplicate animalelor. Valorea biologică a alimentelor de origine vegetală este direct proporțională cu zona geografică şi zona de relief în care sunt cultivate furajele folosite în hrana animalelor, respectiv legumele şi fructele folosite în alimentația umană, la aceastea contribuind: compoziţia, pH-ul şi textura solului, altitudinea - distribuția variației temperaturii şi a precipitațiilor, umiditatea atmosferei, direcția predominantă a vântului, lumina, soarele şi respectiv prezența/absenţa irigării şi a plantelor perene. Aceasta este dată şi de tipul agriculturii aplicate intensivă sau ecologică (34). Riscurile majore pentru sănătatea umană sunt reprezentate de metalele grele $(\mathrm{Pb}, \mathrm{Cu}, \mathrm{Zn}, \mathrm{Hg}, \mathrm{As}, \mathrm{Cd}, \mathrm{Mn}, \mathrm{Ni}, \mathrm{Co}, \mathrm{Al}, \mathrm{Fe}$, Ti) din resursele vegetale, peşti, cereale, tuberculi, apă, aer şi sol $(35,36,42)$. Acestea pot produce neurotoxicitate, cefalee, iritabilitate în cazul $\mathrm{Pb}$ $(37,41,42)$, cancer $(38-40,42)$, leziuni grave ale sistemului de reproducere (41) şi ale tractului gastrointestinal $(41,42)$, leziuni renale şi pulmonare (42), dureri abdominale (42) şi tulburări ale sistemului cardiovascular (42). Utilizarea în condiții necorespunzătoare a pesticidelor, precum recoltarea şi consumul fructelor, legumelor, cerealelor şi tuberculilor în perioada de remanență a pesticidelor, pot conduce la probleme respiratorii (astm, sângerări, bronşită cronică) (43), neuronale şi renale (44). Acumularea pesticidelor în organism poate provoca degradarea metabolică, deficit de atenție, autism, efect neurotoxic $(44,49)$, leziuni miocardice (45), cancer $(46,48,55,57,58)$, tumori cerebrale (47), sindrom metabolic (50). Acestea produc peroxidarea lipidelor, fiind stimulată producția de radicali liberi şi perturbarea capacităţii antioxidante a organismului $(55,59,60)$. Radicalii liberi au efect distructiv asupra colesterolului LDL şi, foarte probabil, sunt responsabili de ateroscleroză $(55,56)$, având şi capacitatea de a schimba structura ADNului $(55,57,58)$.

Pe lângă calitatea fizico- chimică şi senzorială a materiilor prime, valoarea biologică şi senzorială a alimentelor este strict dependentă de tipul tratamentului termic aplicat în timpul procesării alimentelor sau încălzirii acestora (51). Astfel, prin tratarea termică a alimentelor cu ajutorul microundelor, ca de exemplu a fileurilor de somon, scade cantitatea de lipide (52), scade activitatea antioxidantă a apei de cocos (53), creşte degradarea fitosterolului, ceea ce poate conduce la afectarea calității şi siguranței produsului alimentar (54).

Modul de consum şi de percepție a alimentelor influențează percepția mâncării şi sunt influențate de textura, gustul, aroma şi culorile alimentelor. La acestea se adaugă ambientul, muzica, zgomotul şi stresul, precum şi dacă sunt consumate în familie, cu prietenii sau singuri. Alţi factori esențiali sunt obiceiurile alimentare, informațiile nutriționale, factorii cognitivi (61), cunoaşterea compoziției produselor alimentare (61), sensibilitatea gustativă $(62,63)$, vârsta şi sexul (64), greutatea corporală (64), dacă degustătorul/consumatorul este fumător sau nu (64), precum şi consumul anumitor substante farmacologice (65). Mass-media este un factor determinant în modul de consum şi de percepție a alimentelor, atât în România, cât şi în alte țări (66). Hedonismul este influențat inclusiv de muzica ascultată în timpul consumului de alimente sau băuturi alcoolice, de tipul băuturii (67-70), precum şi de celebritățile muzicale care promovează un aliment sau o băutură (69).

Indiferent de domeniul la care se face referire, cromatologia a jucat şi va juca un rol esențial în viața oamenilor, sănătoşi sau suferinzi, ca de exemplu de Alzheimer (71). În Art de la couleur, Johannes Itten afirma: „Culoarea este viața, fiindcă o lume fără culoare se înfățişează moartă (...). Culorile sunt energii radiante care ne influențează în mod pozitiv sau negativ, indiferent dacă ne dăm seama de acest lucru sau nu“ (72). Prin cele trei dimensiuni care pot fi percepute (saturația, luminozitatea şi nuanța), dar şi prin interacțiunea dintre culori, acestea ne pot influența atât starea de sănătate, cât şi emoțională $(72,92)$. Astfel, antocianii sau pigmenții colorați, care sunt responsabili de culorile roşu, violet şi albastru şi care în natură se găsesc în legume şi fructe, au efecte benefice asupra sănătății, ca de exemplu: proprietăți antioxidante (73), antimicrobiene (73), îmbunătătirea activității 
vizuale (73) şi neurologice (73), protecție cardiovasculară (73-77), anticancerigene $(73,78-86)$ şi antidiabetice $(73,87-91)$. Antocianii acționează prin minimum două mecanisme - direct, prin reducerea stresului oxidativ datorită îndepărtării radicalilor liberi, şi indirect, prin reducerea apoptozei celulare şi reglarea proliferării celulare, datorită reducerii stresului oxidativ şi a peroxidării lipidelor (73). Din punct de vedere emoțional, culorile pot scade/creşte ritmul cardiac, creativitatea, puterea de concentrare $(72,92-94,96,99-102)$, ne pot induce sau nu depresia şi starea de nervozitate sau ne pot relaxa (95,97,98-100). În Tabelul 1 sunt reprezentate semnificatiile culorilor din punct de vedere biochimic, respectiv al compoziției fructelor şi legumelor, psihosomatică şi artă (104).

$\mathrm{Ca}$ şi culorile, muzica poate influența starea emoțională (103), conferind stare de relaxare sau stimulare, fericire sau tristețe $(106,107,112)$. Muzica clasică sau de relaxare are efecte terapeutice pozitive în cazul depresiei $(106,109)$, anxietăţii $(106,110)$, stresului $(106,111,112,125)$ şi al bolilor neurodegenerative (106), creşte nivelul de oxitocină şi cortizol (108), scade doza de medicamente sedative şi de analgezice necesare colonoscopiei
$(123,124)$, favorizează legăturile sociale (110). Aceasta reprezintă o terapie alternativă pentru pacientii cu cancer (126).

Servirea minimum a micului dejun şi a cinei în familie contribuie la dezvoltarea echilibrului emoțional şi comunicarea între membrii acesteia. Indiferent de vârstă, pe lângă factorii anterior menționați, consumul de alimente şi apariția suferințelor sunt în relație directă cu stilul de viață. Pe lângă lipsa activității fizice, consumul de alcool şi fumat, poluarea aerului (115), excesul şi frecvența ridicată a consumului de anumite alimente, stilul de viață poate fi unul dintre factorii care influențează homeostazia internă şi stă la baza apariției anumitor suferințe (113), ca de exemplu: scăderea nivelului seric al vitaminei D în cazul consumului unei cantități mari de cafea (113), obezitate (114-116), diabet, riscuri cardiovasculare $(118,119)$, creşterea colesterolului, reflux gastroesofagian (117) etc. Complementar tuturor factorilor menționați şi care pot conduce la apariția suferințelor, un rol important îl au şi factorii socio-demografici. Aceştia pot conduce la suferințe precum demența (120), sindromul intestinului iritabil (121), obezitate, diabet, reflux gastroesofagian, alcoolism (122), depresie

TABELUL 1. Semnificația culorilor din punct de vedere biochimic, psihomatic şi al artei

\begin{tabular}{|c|c|c|}
\hline $\begin{array}{l}\text { Compoziția biochimică } \\
\text { a fructelor legumelor } \\
\text { (alimentelor) }\end{array}$ & Psihosomatică (105) & Artă (72) \\
\hline $\begin{array}{l}\text { Licopen, antociani } \\
\text { ROȘU }\end{array}$ & $\begin{array}{l}\text { Stimularea organismului - energie, putere, curaj, } \\
\text { teamă, consecvență; } \\
\text { Combaterea depresiei, temerilor și melancoliei; } \\
\text { Stimularea poftei de mâncare; } \\
\text { Protejarea celulelor de acțiunea negativă a R•* }\end{array}$ & $\begin{array}{l}\text { Excitant/ iritant, tonic, induce impulsivitate, } \\
\text { dinamism; } \\
\text { Asociere cu sângele, focul, fructe și flori }\end{array}$ \\
\hline $\begin{array}{l}\text { Betacaroten } \\
\text { PORTOCALIU } \\
\end{array}$ & $\begin{array}{l}\text { Optimism, expansivitate, echilibru emoțional, } \\
\text { încredere, schimbare, automotivare. }\end{array}$ & $\begin{array}{l}\text { Tonic, activ, 个pulsul și ritmul respirator; } \\
\text { Asocierea cu căldura, fructe și flori. }\end{array}$ \\
\hline $\begin{array}{l}\text { Bromelaină, luteină, } \\
\text { Zeaxantină } \\
\text { GALBEN }\end{array}$ & $\begin{array}{l}\text { Stimularea intelectului și comunicării, fericire; } \\
\text { Protejarea vederii. }\end{array}$ & $\begin{array}{l}\text { 个pulsul și ritmul respirator, induce veselia; } \\
\text { Asociere cu lumina solară, unele fructe și flori. }\end{array}$ \\
\hline $\begin{array}{l}\text { Clorofila, apigenina, } \\
\text { Luteolin } \\
\text { VERDE }\end{array}$ & $\begin{array}{l}\text { Stimularea sentimentelor de dragoste, echilibru, } \\
\text { armonie, pace, speranță, vindecare, prosperitate; } \\
\text { Protejarea vederii. }\end{array}$ & $\begin{array}{l}\text { Calmare musculară și nervoasă, } \downarrow \text { pulsul și ritmul } \\
\text { respirator; } \\
\text { Asociere spontană cu natura verde. }\end{array}$ \\
\hline $\begin{array}{l}\text { Antociani, resveratrol } \\
\text { ALBASTRU }\end{array}$ & $\begin{array}{l}\text { Urmărirea idealurilor, stimularea inspirației, } \\
\text { creativității, amabilității, răbdării. }\end{array}$ & Răcoare, cer, liniște. \\
\hline $\begin{array}{l}\text { Antociani, resveratrol } \\
\text { ROZ }\end{array}$ & $\begin{array}{l}\text { Stimularea autocunoașterii și intuiției; } \\
\text { Protejarea celulelor de acțiunea negativă a R• }\end{array}$ & Tristețe, instabilitate. \\
\hline $\begin{array}{l}\text { Antoxantine, antioxidanți } \\
\text { flavonoizi } \\
\text { ALB }\end{array}$ & $\begin{array}{l}\text { Smerenie, imaginație creativă, purificare, } \\
\text { perfecțiune; } \\
\downarrow \text { colesterolului și a tensiunii arteriale. }\end{array}$ & Tăcere, pauză, bucurie, curățenie. \\
\hline
\end{tabular}

* R• - radical liber; $\uparrow / \downarrow$ - creștere/scădere. 


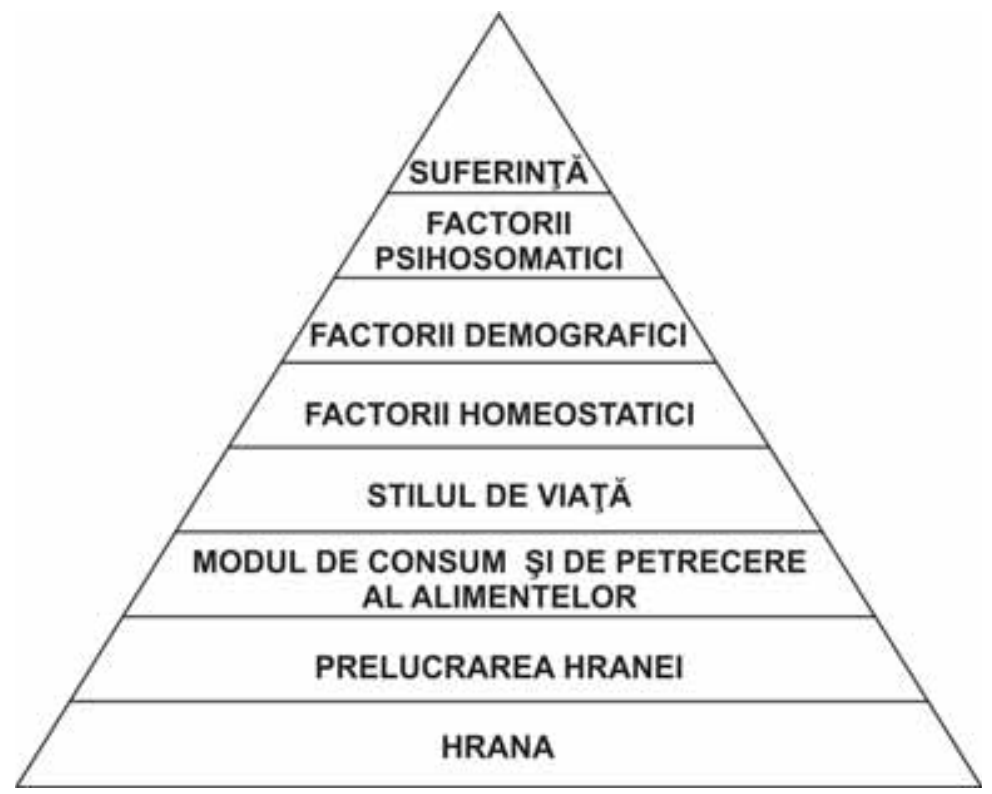

FIGURA 1. Legătura între alimente, factorii psihosociali şi suferință (104)

etc. Prin campaniile şi emisiunile televizate, massmedia poate influența negativ comportamentul populației, în special al femeilor tinere, prin provocarea anxietăţii şi depresiei (129). Din punct de vedere psihosocial, ca şi în cazul altor suferințe, apariția sau prevenirea depresiei este în corelație şi $\mathrm{cu}$ alimentele consumate, prin acțiunea pe care acestea o au asupra mecanismelor fiziopatologice. Fie că depresia este provocată de deficitul de tripto- fan-serotonină (127) sau apare ca reacție adversă în urma tratamentului cu inteferon- $\alpha$, aceasta poate fi tratată cu alimente bogate în triptofan, ca de exemplu lapte, brânză, peşte, ouă, alune, banane, soia (128).

Concluzionând factorii care pot proca suferințe, în Fig. 1 este prezentată legătura între alimente, factorii psihosomatici şi suferinţă.

Conflict of interest: none declared Financial support: none declared

cord injury: the influence of autonomic dysreflexia. J Neurotrauma. 2017;

10. Sánchez-Siles M., Ballester-Ferrandis J.F., Salazar-Sánchez N. et al. Long-term evaluation of quality of life and satisfaction between implant bar overdentures and conventional complete dentures: A 23 years retrospective study. Clin Implant Dent Relat Res. 2017;

11. Tsai W., Lu Q., Perceived Social Support Mediates the Longitudinal Relations between Ambivalence over Emotional Expression and Quality of Life among Chinese American Breast Cancer Survivors. Int J Behav Med. 2017;

12. Pucite E., Krievina I., Miglane E. et al. Influence of Severe Carotid Stenosis on Cognition, Depressive Symptoms and Quality of Life. Clin Pract Epidemiol Ment Health. 2017; 13:168-180.

13. Jongen P.J., Ruinschotel R.P., Museler-Kreijns Y.M. et al. Improved health-related quality of life, participation, and autonomy in patients with treatment-resistant chronic pain after an intensive social cognitive intervention with the participation of support partners. J Pain Res. 2017; 1:2725-2738.

14. Mourão L.C., Garcia E., Passos D. et al. Impact of well-controlled type 2 diabetes mellitus on quality of life of chronic periodontitis patients. J Indian Soc Periodontol. 2016; 20(6):623-626.

15. Müller V., Nabieva N., Häberle L. et al. Impact of disease progression on health-related quality of life in patients with metastatic breast cancer in the PRAEGNANT breast cancer registry. Breast. 2017; 
16. Kamata H., Asakura T., Suzuki S. et al. Impact of chronic Pseudomonas aeruginosa infection on health-related quality of life in Mycobacterium avium complex lung disease. BMC Pulm Med. 2017; 17(1):198.

17. Lee J., Lim J., Park J.S. et al. The Impact of Skin Problems on the Quality of Life in Patients Treated with Anticancer Agents: A Cross-Sectional Study. Cancer Res Treat. 2017.

18. Traina S.B., Slee A., Van Sanden S. et al. An Indirect Comparison of Changes in the Impact of Weight on Quality of Life Among Subjects with Type 2 Diabetes Treated with Antihyperglycemic Agents in Dual Therapy with Metformin. Diabetes Ther. 2017.

19. Watanabe K., Nagao M., Suzuki H. et al. The functional outcome and factors influencing the quality of life after ileal pouch anal anastomosis in patients with ulcerative colitis. Surg Today. 2017.

20. Wong P., Kassam Z., Springer A.N. et al. Long-Term Quality of Life of Retroperitoneal Sarcoma Patients Treated with Pre-Operative Radiotherapy and Surgery. Cureus. 2017; 9(10):e1764.

21. Tonyali S., Haberal H.B., Sogutdelen E., Toxicity, Adverse Events, and Quality of Life Associated with the Treatment of Metastatic Castration-Resistant Prostate Cancer. Curr Urol. 2017; 10(4):169173.

22. Orchard T.S., Andridge R.R., Yee L.D. et al. Diet Quality, Inflammation, and Quality of Life in Breast Cancer Survivors: A Cross-Sectional Analysis of Pilot Study Data. J Acad Nutr Diet. 2017;

23. Shackleford J.L., Minick P., Kelley S.J., Nurses' Perceptions of Quality of Life for Adolescents with Congenital Heart Disease. Compr Child Adolesc Nurs. 2017;13:1-17.

24. Traina S.B., Slee A., Van Sanden S. et al. An Indirect Comparison of Changes in the Impact of Weight on Quality of LifeAmong Subjects with Type 2 Diabetes Treated with Antihyperglycemic Agents in Dual Therapy with Metformin. Diabetes Ther. 2017

25. Watanabe K., Nagao M., Suzuki H. et al. The functional outcome and factors influencing the quality of life after ileal pouch anal anastomosis in patients with ulcerative colitis. Surg Today. 2017

26. Tonyali S., Haberal H.B., Sogutdelen E., Toxicity, Adverse Events, and Quality of Life Associated with the Treatment of Metastatic Castration-Resistant Prostate Cancer. Curr Urol. 2017; 10(4):169173.

27. Orchard T.S., Andridge R.R., Yee L.D. et al. Diet Quality, Inflammation, and Quality of Life in Breast Cancer Survivors: A Cross-Se10.1016/j.jand.2017.09.024ctional Analysis of Pilot Study Data. J Acad Nutr Diet. 2017;

28. Quitadamo P., Zenzeri L., Mozzollo E. et al. Gastric Emptying Time, Esophageal pH-Impedance Parameters, Quality of Life, and Gastrointestinal Comorbidity in Obese Children and Adolescents. J Pediatr. 2017; pii: S0022-3476(17)31450-6.

29. Kellerman R., Kintanar T., Gastroesophageal Reflux Disease. Prin Care. 2017; 44(4):561-573.

30. Andaloro C., Sati M., Grillo C. et al. Relationship between sleeping difficulties and airway symptoms severity with the health-related quality of life in patients with GERD. Minerva Gastroenterol Dietol. 2017; 63(4):307-312.

31. Hosseini M., Salari R., Shariatmaghani S. et al. Gastrointestinal symptoms associated with gastroesophageal reflux disease, and their relapses after treatment with proton pump inhibitors: A systematic review. Electron Physician. 2017; 9(6):4597-4605

32. Fill Malfertheiner S., Seelbach-Göbel B., Costa S.D. et al. Impact of gastroesophageal reflux disease symptoms on the quality of life in pregnant women: a prospective study. Eur J Gastroenterol Hepatol. 2017; 29(8):892-896.

33. Zentilin P., Marabotto E., Pellegatta G. et al. Complexity and diversity of gastroesophageal reflux disease phenotypes. Minerva Gastroenterol Dietol. 2017;63(3):198-204.

34. Mie A., Andersen H.R., Gunnarsson S. et al. Human health implications of organic food and organic agriculture: a comprehensive review. Environ Health. 2017; 16(1):111.

35. Hu W., Huang B., Tian K. et al. Heavy metals in intensive greenhouse vegetable production systems along Yellow Sea of
China: Levels, transfer and health risk. Chemosphere. 2017; 167:82-90.

36. Chanpiwat P., Sthiannopkao S., Widmer K. et al. Assessment of metal and bacterial contamination in cultivated fish and impact on human health for residents living in the Mekong Delta. Chemosphere. 2016; 163:342-350.

37. Bouhouch R.R., El-Fadeli S., Andersson M. et al. Effects of wheat-flour biscuits fortified with iron and EDTA, alone and in combination, on blood lead concentration, iron status, and cognition in children: a double-blind randomized controlled trial. Am J Clin Nutr. 2016; 104(5):1318-1326.

38. Liang Y., Yi X., Dang Z. et al. Heavy Metal Contamination and Health Risk Assessment in the Vicinity of a Tailing Pond in Guangdong, China. Int J Environ Res Public Health. 2017; 14(12). pii: E1557

39. Romaniuk A., Lyndin M., Sikora V. et al. Heavy metals effect on breast cancer progression. J Occup Med Toxicol. 2017; 12:32.

40. Ullah A., Maksud M.A., Khan S.R. et al. Dietary intake of heavy metals from eight highly consumed species of cultured fish and possible human health risk implications in Bangladesh. Toxicol Rep. 2017; 4:574-579.

41. Singh N., Gupta V.K., Kumar A. et al. Synergistic Effects of Heavy Metals and Pesticides in Living Systems., Front Chem. 2017:5:70.

42. Lars Järup, Hazard of heavy metal contamination, Br. Med. Bull. 2003; 68:167-182.

43. Priyadharshini U.K., Latha R., Kavitha U. et al. Effects of Organophosphorus Pesticides on Cardiorespiratory Parameters among the Farmers. J Clin Diagn Res. 2017;

44. Rather I.A., Koh W.Y., Paek W.K. et al. The Sources of Chemical Contaminants in Food and Their Health Implications. Front Pharmacol. 2017;

45. Maheshwari M., Chaudhary S., Acute Atrial Fibrillation Complicating Organophoshourus Poisoning. Heart Views. 2017;18(3):96-99

46. Kigen G., Busakhala N., Kamuren Z. et al. Factors associated with the high prevalence of oesophageal cancer in Western Kenya: a review. Infect Agent Cancer. 2017;

47. Fallahi P., Foddis R., Cristaudo A. et al. High risk of brain tumors in farmers: a mini-review of the literature, and report of the results of a case control study. Clin Ter. 2017;

48. Amizadeh M., Safari-Kamalabadi M., Askari-Sarvazdi G. et al. Pesticide Exposure and Head and Neck Cancers: A Case-Control Study in an Agricultural Region. Iran J Otorhinolarvngol. 2017; 29(94):275-285.

49. Heusinkveld H.J., Westerink R.H.S, Comparison of different in vitro cell models for the assessment of pesticide-induced dopaminergic neurotoxicity. Toxicol In Vitro. 2017; 45(Pt 1):81-88.

50. Rosenbaum P.F., Weinstock R.S., Silverstone A.E. et al. Metabolic syndrome is associated with exposure to organochlorine pesticides in Anniston, AL, United States. Environ Int. 2017; 1

51. Pathera A.K., Riar C.S., Yadav S. et al. Effect of Dietary Fiber Enrichment and Different Cooking Methods on Quality of Chicken Nuggets. Korean J Food Sci Anim Resour. 2017; 37(3):410-417.

52. Bastías J.M., Balladares P., Acuña S. et al. Determining the effect of different cooking methods on the nutritional composition of salmon (Salmo salar) and chilean jack mackerel (Trachurus murphyi)fillets.PLoSOne. 2017;12(7) :e0180993.

53. Valadez-Carmona L., Cortez-García R.M., Plazola-Jacinto C.P. et al.Effect of microwave drying and oven drying on the water activity, color, phenolic compounds content and antioxidant activity of coconut husk (Cocos nucifera L.). J Food Sci Technol. 2016; 53(9):3495-3501.

54. Leal-Castañeda E.J., Inchingolo R., Cardenia V. et al. Effect of Microwave Heating on Phytosterol Oxidation. J Agric Food Chem. 2015; 63(22):5539-47.

55. Abdollahi M., Ranjbar A., Shadnia S. et al. Pesticides and oxidative stress: a review. Med Sci Monit. 2004; 10(6):RA141-147.

56. Rumley A.G., Paterson J.R. Analytical aspects of antioxidants and free radical activity in clinical biochemistry. Ann Clin Biochem. 1998; 35: 181-200. 
57. Lioi M.B., Scarfi M.R., Santoro A. et al. Genotoxicity and oxidative stress induced by pesticide exposure in bovine lymphocyte cultures in vitro. Mutat Res. 1998; 403: 13-20.

58. Banerjee B.D., Seth V., Ahmed R.S. Pesticide-induced oxidative stress: perspectives and trends. Rev Environ Health. 2001; 16: 1-40.

59. Banerjee B.D., Seth V., Bhattacharya A. et al. Biochemical effects of some pesticides on lipid peroxidation and freeradical scavengers. Toxicol Lett, 1999; 107: 33-47.

60. Etemadi-Aleagha A., Akhgari M., Abdollahi M. A brief review on oxidative stress and cardiac diseases. Mid East Pharmac. 2002; 10: 8-9.

61. Procencher V., Jacob R., Impact of Perceived Healthiness of Food on Food Choices and Intake. Curr Obes Rep.2016; 5(1):65-71.

62. Tepper B.J. Nutritional implications of genetic taste variation: The role of PROP sensitivity and other taste phenotypes. Annu. Rev. Nutr. 2008; 28:367-388.

63. Tepper B.J. 6-n-Propylthiouracil: A genetic marker for taste, with implications for food preference and dietary habits. Am. J Hum. Genet. 1998; 63: 1271-1276.

64. Tepper B.J., Melis M., Koelliker Y. et al. Factors Influencing the Phenotypic Characterization of the Oral Marker, PROP. Nutrients. 2017; 9(12)

65. Garcez Nabuco H.C., Behrends Rodrigues V., Souza Fernandes V.L. et al. Factors associated with dietary supplementation among Brazilian athletes. Nutr. Hosp. 2016; 33(3):278.

66. Tayyem R.F., Bawadi H.A., AbuMweiss S.S. et al. Association between mass media and body weight concern among Jordanian adolescents' residents of Amman: the role of gender and obesity. Environ Health Prev.Med. 2016; 21(6):430-438.

67. Carvalho F.R., Velasco C., Raymond van Ee. et al. Music Influences Hedonic and Taste Ratings in Beer. Frontiers in Psychology. 2016;7:

68. Mallik A., Chanda M.L., Levitin D.J., Anhedonia to music and mu-opioids: Evidence from the administration of naltrexone. Sci. Rep. 2017; 7:41952.

69. Bragg M.A., Miller A.N., Elizee J. et al. Popular Music Celebrity Endorsements in Food and Nonalcoholic Beverage Marketing. Pediatrics. 2016; 138(1). pii:e20153977

70. Kong K.L., Eiden R.D., Feda D.M. et al. Reducing relative food reinforcement in infants by an enriched musicexperience. Obesity (Silver Spring). 2016; 24(4):917-23.

71. Wilson D.W., Nash P., Buttar H.S. et al. The Role of Food Antioxidants, Benefits of Functional Foods, and Influence of Feeding Habits on the Health of the Older Person: An Overview. Antioxidants (Basel). 2017; 6(4).pii:E81.

72. Lăzărescu L., Culoarea în artă. Editura Polirom, laşi, 2009.

73. Khoo H.E., Azlan A., Tang S.T. et al. Anthocyanidins and anthocyanins: colored pigments as food, pharmaceutical ingredients, and the potential health benefits. Food Nutr. Res. 2017; 61(1): 1361779.

74. Rechner A.R., Kroner C. Anthocyanins and colonic metabolites of dietary polyphenols inhibit platelet function. Thromb Res. 2005; 116(4):327-334.

75. Bell D.R., Gochenaur K. Direct vasoactive and vasoprotective properties of anthocyanin-rich extracts. J Appl Physiol. 2006; 100(4):1164-1170.

76. Toufektsian M.C., De Lorgeril M., Nagy N. et al. Chronic dietary intake of plant-derived anthocyanins protects the rat heart against ischemia-reperfusion injury. J Nutr. 2008; 138(4):747-752.

77. Alvarez-Suarez J.M., Giampieri F., Tulipani S. et al. One-month strawberry-rich anthocyanin supplementation ameliorates cardiovascular risk, oxidative stress markers and platelet activation in humans. J Nutr Biochem. 2014; 25(3):289-294.

78. Wang L.S., Hecht S.S., Carmella S.G. et al. Anthocyanins in black raspberries prevent esophageal tumors in rats. Cancer Prev Res. 2009; 2(1):84-93.

79. Faria A., Pestana D., Teixeira D. et al. Blueberry anthocyanins and pyruvic acid adducts: anticancer properties in breast cancer cell lines. Phytother Res. 2010; 24(12):1862-1869.
80. Hui C., Bin Y., Xiaoping Y. et al. Anticancer activities of an anthocyanin-rich extract from black rice against breast cancer cells in vitro and in vivo. Nutr Cancer. 2010; 62(8):1128-1136.

81. Chen X.Y., Zhou J., Luo L.P. et al. Black rice anthocyanins suppress metastasis of breast cancer cells by targeting RAS/RAF/ MAPK pathway. BioMed Res Int. 2015; 2015:414250.

82. Malik M., Zhao C., Schoene N. et al. Anthocyanin-rich extract from Aronia meloncarpa $\mathrm{E}$. induces a cell cycle block in colon cancer but not normal colonic cells. Nutr Cancer. 2003; 46(2):186-196.

83. Lala G., Malik M., Zhao C. et al. Anthocyanin-rich extracts inhibit multiple biomarkers of colon cancer in rats. Nutr Cancer. 2006; 54(1):84-93.

84. Lim S., Xu J., Kim J. et al. Role of anthocyanin-enriched purple-fleshed sweet potato p40 in colorectal cancer prevention. Mol Nutr Food Res. 2013; 57(11):1908-1917.

85. Jang H., Ha U.S., Kim S.J. et al. Anthocyanin extracted from black soybean reduces prostate weight and promotes apoptosis in the prostatic hyperplasia-induced rat model. J Agric Food Chem. 2010; 58:12686-12691

86. Shin D.Y., Lee W.S., Kim S.H. et al. Anti-invasive activity of anthocyanins isolated from Vitis coignetiae in human hepatocarcinoma cells. J Med Food. 2009; 12(5):967-972.

87. Takikawa M., Inoue S., Horio F. et al. Dietary anthocyanin-rich bilberry extract ameliorates hyperglycemia and insulin sensitivity via activation of AMP-activated protein kinase in diabetic mice. J Nutr. 2010; 140(3):527-533.

88. Li D., Zhang Y., Liu Y. et al. Purified anthocyanin supplementation reduces dyslipidemia, enhances antioxidant capacity, and prevents insulin resistance in diabetic patients. J Nutr. 2015; 145(4):742-748.

89. Kang M.K., Lim S.S., Lee J.Y. et al. Anthocyanin-rich purple corn extract inhibit diabetes-associated glomerular angiogenesis. Plos One. 2013;8(11):e79823.

90. Koh E.S., Lim J.H., Kim M.Y. et al. Anthocyanin-rich Seoritae extract ameliorates renal lipotoxicity via activation of AMP-activated protein kinase in diabetic mice. J Trans/ Med. 2015; 13:203.

91. Liu Y., Li D., Zhang Y. et al. Anthocyanin increases adiponectin secretion and protects against diabetes-related endothelial dysfunction. Am J Physiol Endocrinol Metab. 2014; 306(8):E975E988.

92. Wilms L., Oberfeld D., Color and emotion: effects of hue, saturation, and brightness. Psychol Res. 2017.

93. Yuda E., Ogaswara H., Yoshida Y. et al. Suppression of vagal cardiac modulation by blue light in healthy subjects. J Physiol Anthropol. 2016; 35(1):24

94. Weitbrecht W.U., Bärwolff H., Lischke A. et al. Effect of Light Color Temperature on Human Concentration and Creativity. Fortschr Neurol Psychiatr. 2015; 83(6):344-8.

95. Sroykham W., Wongsathikun J., Wongawat Y., The effects of perceiving color in living environment on QEEG, oxygen saturation, pulse rate, and emotion regulation in humans. Conf Proc IEEE Eng Med Biol Soc. 2014; 2014:6226-9.

96. Dreiskaemper D., Strauss B., Hagemann N. et al. Influence of red jersey color on physical parameters in combat sports. J Sport Exerc Psychol. 2013; 35(1):44-9.

97. Akers A., Barton J., Cossey R. et al. Visual color perception in green exercise: positive effects on mood and perceived exertion. Environ Sci Technol. 2012; 46(16):8661-6.

98. Sakuragi S., Sugiyama Y., Effect of partition board color on mood and autonomic nervous function. Percept Mot Skills. 2011; 113(3):941-56.

99. Barkat S., Thomas-Danguin T., Bensafi M. et al. Odor and color of cosmetic products: correlations between subjective judgement and autonomous nervous system response. Int J Cosmet Sci. 2003; 25(6):273-83.

100. Buchner A., Baumgartner N., Text - background polarity affects performance irrespective of ambient illumination and colour contrast. Ergonomics. 2007; 50(7):1036-63.

101. Shindo M., Kasai T., Abe A. et al. Effects of dietary administration of plant-derived anthocyanin-rich colors to spontaneously hypertensive rats. J Nutr Sci Vitaminol (Tokyo). 2007; 53(1):90-3. 
102. Schäfer A., Kratky K.W., The effect of colored illumination on heart rate variability. Forsch Komplementmed. 2006; 13(3):167-73.

103. Arjmand H.A., Hohagen J., Paton B. et al. Emotional Responses to Music: Shifts in Frontal Brain Asymmetry Mark Periods of Musical Change. Front Psychol. 2017; 8:2044.

104. Matran I.M., Dumitraşcu D.L., Legătura dintre alimente, factorii psihosociali şi suferinţă, Simpozion psihosomatică, Braşov, 2017

105. Dahlke R., Boala ca simbol. Manual de psihosomatică. Editura Adevăr Divin, Braşov, 2014.

106. Schaefer H.E., Music-Evoked Emotions-Current Studies. Front Nurosci. 2017;11:600.

107. Chanda M.L., Levitin D.J., The neurochemistry of music. Trends Cogn. Sci. 2013;17:179-193.

108. Ooishi Y., Mukai H., Watanabe K. et al. Increase in salivary oxytocin and decrease in salivary cortisol after listening to relaxing slow-tempo and exciting fast-tempo music. PLoS One. 2017; 12(12): e0189075.

109. Aalbers S., Fusar-Poli L., Freeman R.E. et al. Music therapy for depression. Cochrane Database Syst Rev. 2017; 11:CD004517.

110. Horuz D., Kurcer M.A., Erdoğan Z., The Effect of Music Therapy on Anxiety and Various Physical Findings in Patients With COPD in a Pulmonology Service. Holist Nurs Pract. 2017; 31(6):378-383

111. Gäbel C., Garrido N., Koenig et al. Effects of Monochord Music on Heart Rate Variability and Self-Reports of Relaxation in Healthy Adults. Complement Med Res. 2017; 24(2):97-103.

112. Lee K.S., Jeong H.C., Yim J.E. et al. Effects of Music Therapy on the Cardiovascular and Autonomic Nervous System in StressInduced University Students: A Randomized Controlled Trial. J Altern Complement Med. 2016; 22(1):59-65.

113. Lim H.S., Lee H.H., Byun D.W. et al. Serum Vitamin D Level Related to Coffee Consumption in Korean Young Adults Using the 5th Korea National Health and Nutrition Examination Survey. J Bone Metab. 2017; 24(4):229-233.

114. Aryeetey R., Lartey A., Marquis G.S. et al. Prevalence and predictors of overweight and obesity among school-aged children in urban Ghana. BMC Obes.; 4:38.

115. Marabelli C., Munarini E., Lina M. et al. A pilot study with early adolescents: dealing with diet, tobacco and air pollution using practical experiences and biological markers. Multidiscip Respir Med. 2017;12:30.

116. Puia A., Leucuta D.C., Children's lifestyle behaviors in relation to anthropometric indices: a family practice study. Clujul Med. 2017; 90(4):385-391.
117. Alkhathami A.M., Alzahrani A.A., Alzhrani M.A. et al. Risk Factors for Gastroesophageal Reflux Disease in Saudi Arabia. Gastroenterology Res. 2017; 10(5):294-300.

118. Lai S., Mastroluca D., Matino S. et al. Early Markers of Cardiovascular Risk in Autosomal Dominant Polycystic Kidney Disease. Kidney Blood Press Res. 2017; 42(6):1290-1302.

119. Oh T.K., Song I.A., Park Y.M. et al. Prevalence and risk factors for postoperative stress-related cardiomyopathyin adults. PLoSOne. 2017; 12(12):e0190065.

120. Chaaya M., Phung K., Atweh S. et al. Socio-demographic and cardiovascular disease risk factors associated with dementia: Results of a cross-sectional study from Lebanon. Prev Med Rep. 2017:9:1-5

121. Adeniyi O.F., Adenike Lesi O., Olatona F.A. et al. Irritable bowel syndrome in adolescents in Lagos. Pan Afr Med J. 2017;28:93.

122. Paulsson-Do U., Edlund B., Stenhammar C. et al. Psychosocial vulnerability underlying four common unhealthy behaviours in 15-16-year-old Swedish adolescents: a cross-sectional study. BMC Psychology. 2017; 5:39.

123. Lee D.W., Chan K.W., Poon C.M. et al. Relaxation music decreases the dose of patient-controlled sedation during colonoscopy:a prospective randomized controlled trial. Gastrointest Endosc. 2002; 55(1):33-6.

124. Schiemann U., Gros M., Reuter R. et al. Improved procedure of colonoscopy under accompanying music therapy. Eur J Med Res. 2002; 7(3):131-4.

125. Corah N.L., Gale E.N., Pace L.F. et al. Relaxation and musical programming as means of reducing psychologicalstress during dental procedures. J Am Dent Assoc. 1981; 103(2):232-4.

126. Cassileth B.R., Evaluating complementary and alternative therapies for cancer patients. CA Cancer J Clin. 1999; 49(6):362-75.

127. Beranyi A., Amouzadeh-Ghadikolai O., von Lewinski D. et al. Revisiting the tryptophan-serotonin deficiency and the inflammatory hypotheses of major depression in a biopsychosocial approach. PeerJ.2017; 5:e3968.

128. Azimi Fashi Y., Mesripour A., Hajhashemi V. Evaluation of the effect of soybean diet on interferon-a-induced depression in male mice.Avicenna J Phytomed.2017;7(5):436-443.

129. Barcaccia B., Balestrini V., Saliani A.M. et al. Dysfunctional eating behaviors, anxiety, and depression in Italian boys and girls: the role of mass media. Rev Bras Psiguiatr. 2017: 0. doi: 10.1590/15164446-2016-2200. 